\title{
Pemanfaatan Model WRF-ARW untuk Analisis Fenomena Atmosfer Borneo Vortex (Studi Kasus Tanggal 28 Desember 2014)
}

\author{
Randy Ardianto ${ }^{1 *}$ \\ ${ }^{1}$ Badan Meteorologi Klimatologi dan Geofisika \\ Stasiun Meteorologi Maritim Pontianak \\ *Email : randy.ardianto@bmkg.go.id
}

\begin{abstract}
Abstrak
Penelitian ini memanfaatkan model WRF-ARW (Weather Research and Forcasting - Advanced Research $W R F$ ) untuk memberikan gambaran mengenai kondisi atmosfer saat kejadian Borneo Vortex. Hasil visualisasi model WRF-ARW pada tanggal 28 Desember 2014 menunjukkan adanya vortex, dimana hal ini menimbulkan belokan angin dan arus konvergen di Laut Cina Selatan, Selat Karimata, dan Kalimantan bagian selatan. Selain itu kondisi atmosfer yang labil dan kelembaban udara yang tinggi saat itu, memicu terbentuknya awan-awan konvektif pada ketiga wilayah tersebut. Uji kehandalan sederhana pada model menunjukkan bahwa secara spasial model mampu memetakan wilayah-wilayah yang terdapat hujan dengan baik namun dari segi intensitas hujan, angka yang dihasilkan oleh model tergolong underestimate jika dibandingkan dengan data TRMM 3B42.
\end{abstract}

Kata Kunci: Borneo vortex, WRF-ARW

\section{Latar Belakang}

Borneo vortex merupakan fenomena yang cukup diperhitungkan dalam analisis dan prakiraan cuaca karena berpengaruh terhadap pola angin dan peningkatan curah hujan di sekitar pulau Kalimantan dan Laut Cina Selatan. Keberadaan vortex ini juga berdampak terhadap terhambatnya pasokan uap air dari benua Asia yang akan melewati pulau Jawa sebelum akhirnya mencapai benua Australia. Menurut Anip dan Lupo[1], Braesicke dkk[2] Borneo vortex adalah sirkulasi angin tertutup yang tampak secara jelas diatas Laut Cina Selatan ekuator dan benua maritim Indonesia bagian barat atau pesisir barat pulau Kalimantan, selama musim dingin di Belahan Bumi Utara (BBU) berlangsung. Menurut Chang dkk[3] Borneo vortex teridentifikasi ketika terjadi sirkulasi tertutup yang berlawanan dengan arah jarum jam pada angin $925 \mathrm{hPa}$ di area $2.5^{\circ} \mathrm{LS}$ - $7.5^{\circ} \mathrm{LU}, 107.5^{\circ} \mathrm{BT}$ - $117.5^{\circ} \mathrm{BT}$. Selain itu dalam periode bulanannya, bulan Desember merupakan puncak kejadian Borneo vortex yang didasarkan pada frekuensi kejadian dan masa hidupnya. Menurut Lupo dan Anip[4]rata-rata suatu sistem vortex memiliki masa hidup 3.6 hari yang menunjukkan bahwa vortex tersebut adalah fenomena cuaca skala sinoptik.

Menurut Chang dkk[3] pada hari-hari tanpa adanya Borneo vortex, konsentrasi konveksi cenderung mengalami penurunan massa udara (suppressed area) di Laut Cina Selatan dan Kalimantan serta mengalami kenaikan massa udara (enhanced area) di atas daratan sebelah barat dan selatan ekuator Laut Cina Selatan (Sumatera dan Jawa). Pola ini terbalik pada harihari dimana terdapat Borneo vortex, dimana daerah enhanced area terjadi di Laut Cina Selatan dekat ekuator dan Kalimantan. Menurut Lupo dan Anip[4], Houze dkk[5], Jhonson dan Priegnitz[6], kehadiran Borneo vortex ini telah lama dikaitkan dengan masa aktif monsun dingin Asia yang mengarah kepada aktivitas hujan deras dan bencana banjir.

Penelitian ini mengkaji studi kasus Borneo vortex dengan menerapkan salah satu skema parameterisasi pada model WRF-ARW (Weather Research and Forcasting - Advanced Research WRF). Menurut Sulung dkk[7] parameterisasi kumulus merupakan salah satu cara untuk meninjau pembentukan awan kumulus akibat efek 
konvektif pada model. Dalam memparameterisasi proses-proses fisis di alam diperlukan skema yang didasarkan pada formulasi fisis atau formula statistik yang diturunkan dari variabel sehingga dapat diprediksi suatu model. Studi kasus tanggal 28 Desember 2014 dipilih karena pada tanggal tersebut terlihat aktivitas pertumbuhan awan secara massive di sekitar Laut Cina Selatan dan pulau Kalimantan. Analisis hasil output model dari skema parameterisasi model WRF-ARW dilakukan dalam skala meso diharapkan dapat memberikan gambaran megenai kondisi atmosfer saat kejadian Borneo vortex.

\section{Metodologi}

\subsection{Lokasi Penelitian}

Lokasi penelitian ini adalah wilayah sekitar Laut Cina Selatan dan pulau Kalimantan (Gambar 1). Wilayah ini dipilih karena secara menurut Chang dkk.[3] merupakan daerah yang terdampak oleh Borneo vortex.

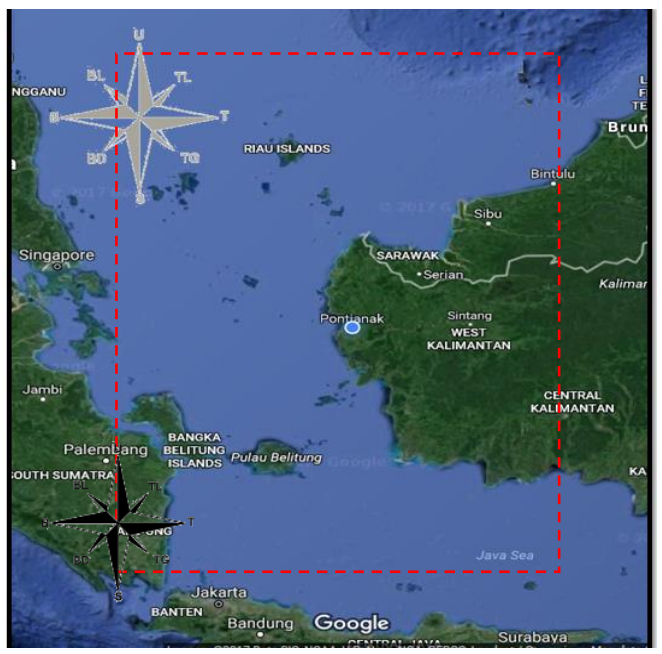

Gambar 1. Peta lokasi penelitian.[8]

\subsection{Data}

Dalam penelitian ini digunakan beberapa data yang digunakan antara lain :

1. Initial dan boundary condition dari model digunakan data FNL (Final Global Data Assimilation System) tanggal 27 Desember 2014 Pukul 12.00 UTC - 29 Desember 2014 pukul 12.00 UTC, interval waktu 6 jam [9].

2. Data harian tanggal 28 Desember 2014 Tropical Rainfall Measuring Mission (TRMM 3B42) v7, resolusi data $0.25^{\circ} \times 0.25^{\circ}$ [10].
3. Data satelit MTSAT tanggal 28 Desember 2014, diperoleh dari Badan Meteorologi Klimatologi dan Geofisika (BMKG) [11].

4. Data analisis pola angin lapisan $925 \mathrm{hPa}$ dari Bireu of Meteorology Australia (BOM) [12].

\subsection{Alat Penelitian}

Penelitian ini menggunakan beberapa alat untuk melakukan eksperimen antara lain:

a. Model WRF-ARW V.3.1.1 dan WRF Domain Wizard

Model WRF-ARW V.3.1.1 merupakan model yang dirilis pada bulan April 2009 [13]. NOAA dan AFWA menjadi pengembang utama model ini yang dibantu oleh National Science Foundation (NSF).

b. Grid Analysis and Display System Versi 2.0

GrADS adalah aplikasi interaktif yang digunakan untuk memudahkan akses, manipulasi dan visualisasi dari suatu data ilmu kebumian. Aplikasi ini dikembangkan oleh bagian riset National Aeronautics and Space Administration (NASA), Center for Ocean-Land-Atmosphere Studies (COLA) dan NSF [14].

c. Parameter Ukur

Dalam memahami kekuatan suatu vortex, terdapat variabel fisis yang dapat digunakan sebagai ukuran kekuatan dari fenomena atmosfer ini yaitu vortisitas. Menurut Holton[15], Lynch dan Cassano[16] bahwa vortisitas merupakan sebuah konsep matematika yang digunakan dalam menggambarkan gerakan berputar dari parsel udara. Semakin besar vortisitas maka sebuah vortex akan semakin lebih kuat, selain itu nilai vortisitas positif di BBU menunjukkan adanya kenaikan masa udara dan penurunan massa udara bila bernilai negatif. Vortisitas absolut $\omega a$ adalah curl dari kecepatan absolut sedangkan vortisitas relatif $\omega$ adalah curl dari kecepatan relatif yang dinyatakan dengan persamaan [15]:

$$
\zeta \equiv \frac{\delta v}{\delta x}-\frac{\delta u}{\delta y}
$$


POSITRON, Vol. VII, No. 1 (2017), Hal. 01 - 07

http://dx.doi.org/10.26418/positron.v7i1.19349

Dimana :

$\zeta$ Vortisitas relatif

$\frac{\delta v}{\delta x}$ Laju perubahan komponen angin $\mathrm{v}$ sumbu $\mathrm{x}$

$\frac{\delta u}{\delta y}$ Laju perubahan komponen angin u sumbu y

Borneo Vortex membentuk daerah konvergensi pada troposfer lapisan bawah sehingga menyebabkan terjadinya konveksi mekanis kuat di sekitar wilayah tersebut. Convective Available Potential Energy (CAPE) adalah salah satu indikator yang kuat untuk mengindikasi adanya potensi intensitas konvektif dan dapat digunakan untuk mengukur kelabilan atmosfer (Tabel 1). CAPE merupakan jumlah energi dari suatu parsel saat terangkat pada jarak tertentu secara vertikal di atmosfer. CAPE diukur dalam satuan $(\mathrm{J} / \mathrm{kg})$ [14]. CAPE dapat dinyatakan dengan persamaan [15]:

$$
C A P E=\int_{{ }^{z} L F C}^{{ }^{L N B}} g\left(\frac{T_{\text {parcel }}-T_{e n v}}{T_{e n v}}\right) d z
$$

Dimana :

${ }^{z}$ LNB Ketinggian dari lapisan neutral buoyancy.

${ }^{z}$ LFC Ketinggian dari lapisan free convection.

$g \quad$ Gravitasi bumi.

$T_{\text {parcel }}$ Suhu parsel udara.

$T_{e n v} \quad$ Suhu lingkungan di sekitar parsel udara.

Tabel 1. Kategori CAPE [17]

\begin{tabular}{|c|c|c|}
\hline No. & Nilai CAPE & $\begin{array}{c}\text { Ketidakstabilan } \\
\text { Atmosfer }\end{array}$ \\
\hline 1 & $<1000 \mathrm{~J} / \mathrm{Kg}$ & Weak Instability \\
\hline 2 & $1000-2500 \mathrm{~J} / \mathrm{Kg}$ & Moderate Instability \\
\hline 3 & $2500-4000 \mathrm{~J} / \mathrm{Kg}$ & Strong Instability \\
\hline 4 & $>4000 \mathrm{~J} / \mathrm{Kg}$ & Extreme Instability \\
\hline
\end{tabular}

ISSN: 2301-4970 (print )

ISSN: 2549-936X (online)

\subsection{Diagram Alir Penelitian}

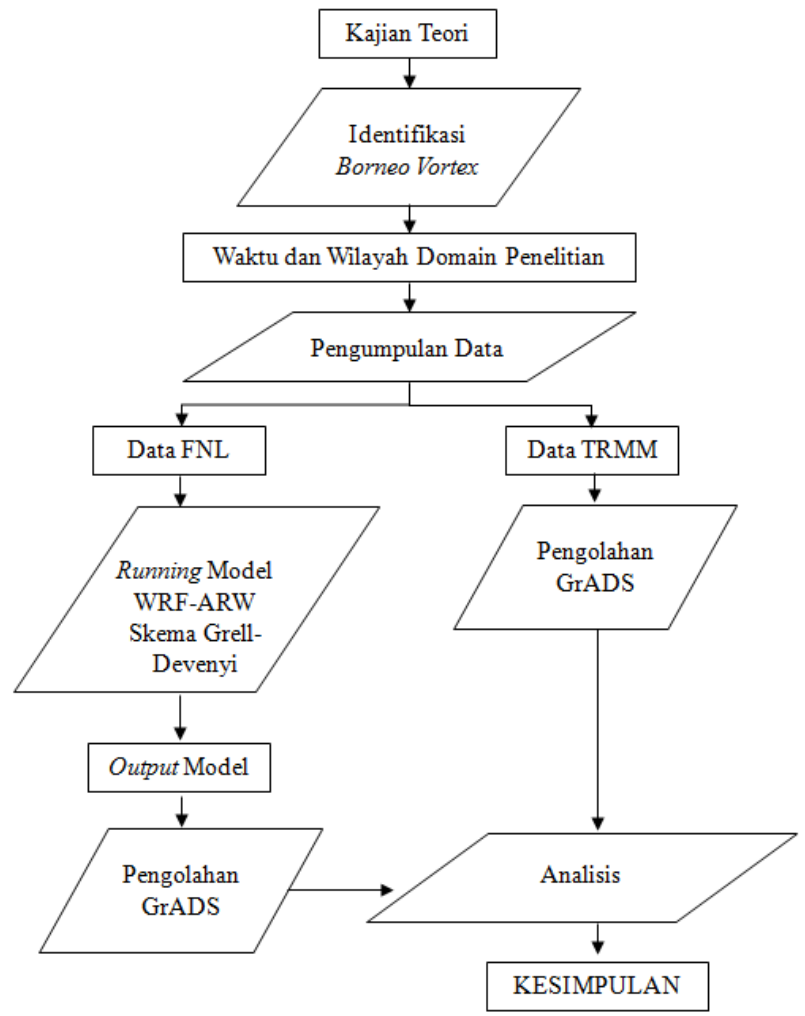

Gambar 2. Diagram alir penelitian.

\section{Hasil dan Pembahasan}

\subsection{Identifikasi Borneo Vortex}

Borneo vortex dapat diidentifikasi dengan menggunakan pola angin pada lapisan $925 \mathrm{hPa}$ tanggal 28 Desember 2014.

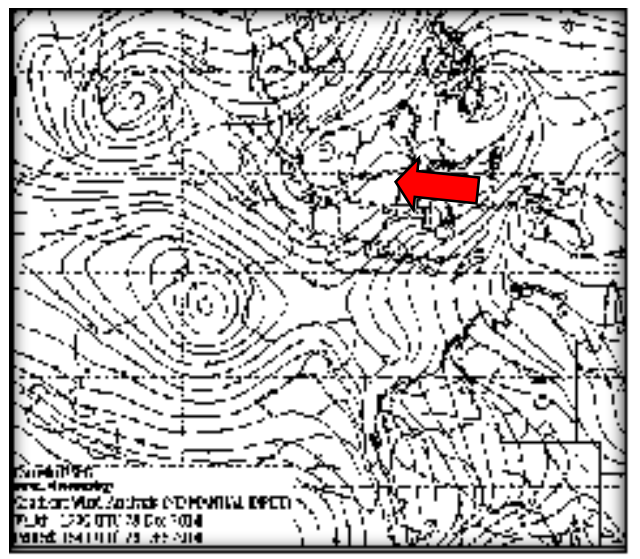

Gambar 3. Pola analisis angin BOM

Berdasarkan data analisis pola angin (Gambar 3) terdapat pola angin yang berputar atau Borneo vortex tanggal 28 Desember 2014. Adanya vortex tersebut menyebabkan perubahan 
pola angin jika dibandingkan dengan pola angin di hari tanpa adanya vortex.

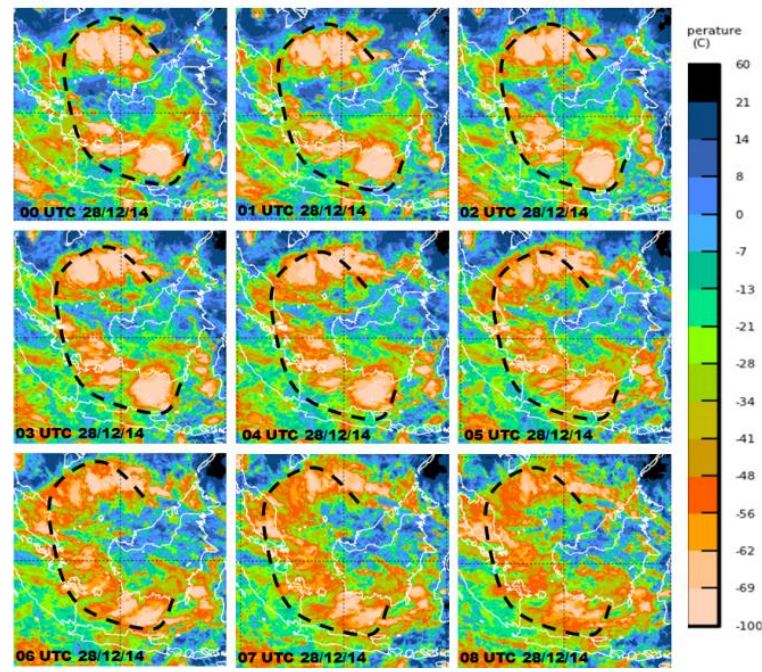

Gambar 4. Citra satelit MTSAT tgl. 28 Desember 2014 pukul 00 UTC hingga 08 UTC.

Berdasarkan citra satelit MTSAT (Gambar 4) terdapat aktivitas pertumbuhan awan konvektif yang memiliki pola yang hampir sama selama 9 (sembilan) jam sebelum kemudian semakin melemah dan berganti pola. Terlihat dari garis putus-putus menunjukkan pola liputan awan terpusat di Laut Cina Selatan dan sekitar pulau Kalimantan, hal ini sesuai dengan teori Chang, dkk[3] bahwa pada hari dimana terdapat Borneo vortex kenaikan massa udara cenderung aktif di atas Laut Cina Selatan dan sekitar pulau Kalimantan.

\subsection{Hasil Visualisasi Model}

\subsubsection{Streamline angin lapisan $925 \mathrm{hPa}$}

Borneo vortex merupakan gerakan angin memutar siklonik pada lapisan $925 \mathrm{hPa}$ hingga mencapai $500 \mathrm{hPa}$. Adanya vortex ini menyebabkan terjadinya perubahan pola angin dimana akan terbentuk daerah siklonik, netral, belokan, perlambatan kecepatan dan daerah yang mengalami konvergensi. Hasil visualisasi dari kondisi arah dan kecepatan angin (Gambar 5) menunjukkan bahwa dari model mendeteksi adanya Borneo vortex. Berdasarkan gambar tersebut vortex terbentuk hanya pada troposfer lapisan bawah (925 hPa dan $850 \mathrm{hPa}$ ) sedangkan pada lapisan atas (300 hPa) vortex tidak lagi ditemukan.

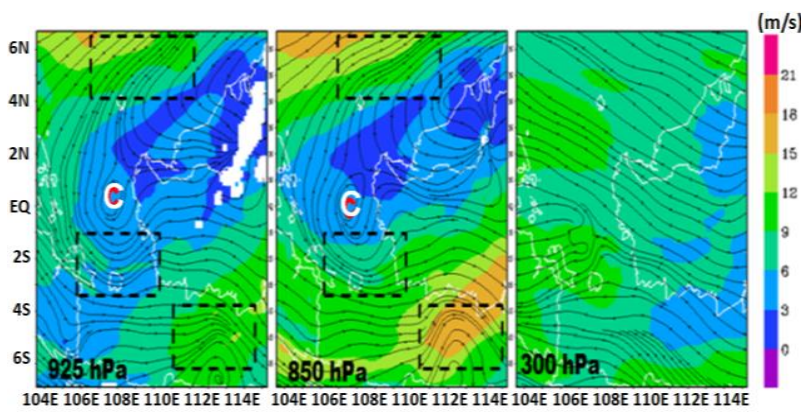

Gambar 5. Arah dan kecepatan angin harian tgl 28

Desember 2014, “c" menunjukkan siklonik.

Hal tersebut menguatkan teori bahwa vortex memang lebih berdampak langsung terhadap perubahan pola angin di lapisan bawah. Selain itu, keberadaan vortex ini membentuk belokan angin dan arus konvergen (penumpukan) massa udara di Laut Cina Selatan, Selat Karimata dan Selatan Kalimantan yang berimbas terjadinya potensi pembentukan awan konvektif pada ketiga wilayah tersebut.

\subsubsection{Vortisitas}

Nilai vortisitas pada model (Gambar 6) menunjukkan daerah sekitar vortex bernilai positif kuat (area warna merah) yaitu lebih dari 6 x $10^{5} \mathrm{~s}^{-1}$ mulai dari lapisan $925 \mathrm{hPa}$ hingga lapisan $700 \mathrm{hPa}$ dibandingan dengan daerah lain yang kurang dari $3 \times 10^{5} \mathrm{~s}^{-1}$ (area warna putih).

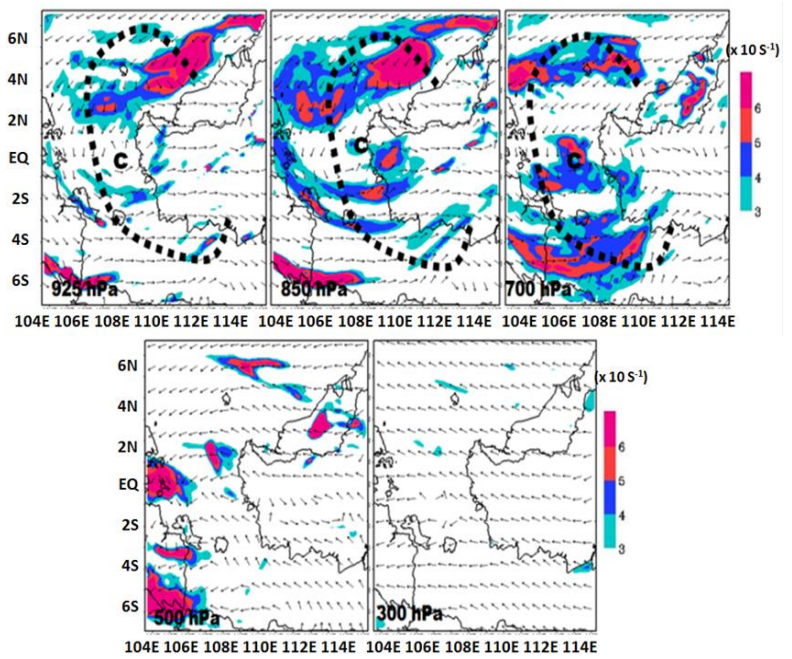

Gambar 6. Vortisitas relatif harian tgl. 28 Desember 2014, "c" menunjukkan siklonik. 
Hal ini menandakan vortex ini termasuk vortex yang cukup kuat. Selain itu nilai vortisitas positif di BBU dan sekitar ekuator menunjukkan adanya kenaikan masa udara dan penurunan massa udara bila bernilai negatif [12]. Terlihat dari pola sebaran vortisitas menunjukkan pola yang mirip dengan pertumbuhan awan pada citra satelit (Gambar 5).

\subsubsection{Kelembaban Udara}

Hasil keluaran model untuk kelembaban udara (Gambar 6), menunjukkan pada lapisan 925 hPa kelembaban udara di sekitar Laut Cina Selatan dan Kalimantan mencapai 90-99\%, lapisan $850 \mathrm{hPa}$ berkisar pada 80-95\%, dan lapisan $700 \mathrm{hPa}$ kelembaban udara berkisar pada 75-90\% serta lapisan $500 \mathrm{hPa}$ berkisar pada 80 $95 \%$.

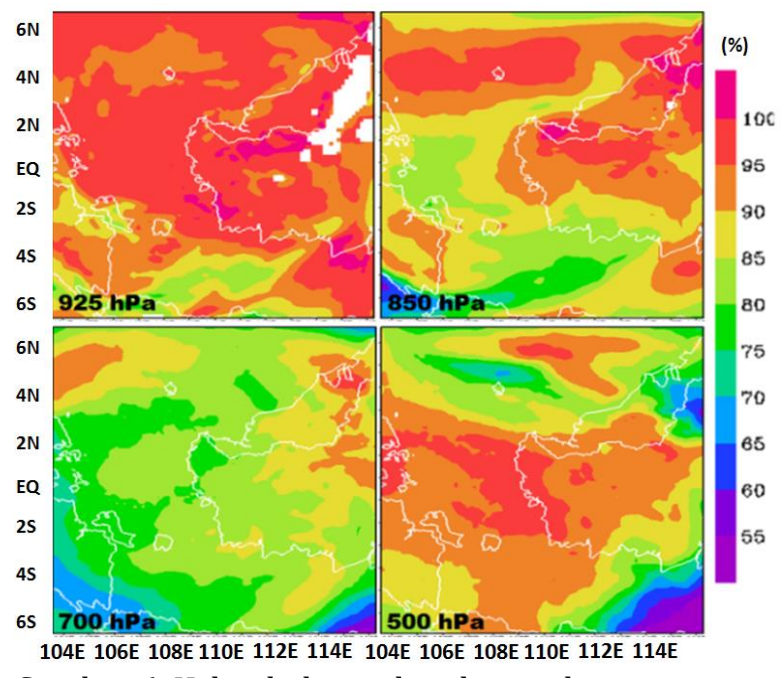

Gambar 6. Kelembaban udara harian lapisan signifikan a) 925 b) 850 c) 700 d) 500 hPa.

Kelembaban udara merupakan komponen penting dalam mendukung pertumbuhan awan, tanpa adanya ketersediaan uap air yang cukup maka pertumbuhan awan akibat konvergensi yang ditimbulkan Borneo vortex akan menjadi tidak maksimal. Secara umum kondisi atmosfer di sekitar Laut Cina Selatan dan Kalimantan pada kasus ini dalam keadaan yang basah, sehingga ketersediaan uap air menjadi terpenuhi untuk mendukung proses pembentukan awan konvektif.

\subsubsection{Convective Available Potential Energy (CAPE)}

CAPE merupakan salah satu indikator yang kuat untuk mengindikasi adanya potensi intensitas konvektif dan dapat digunakan untuk mengukur kelabilan atmosfer.

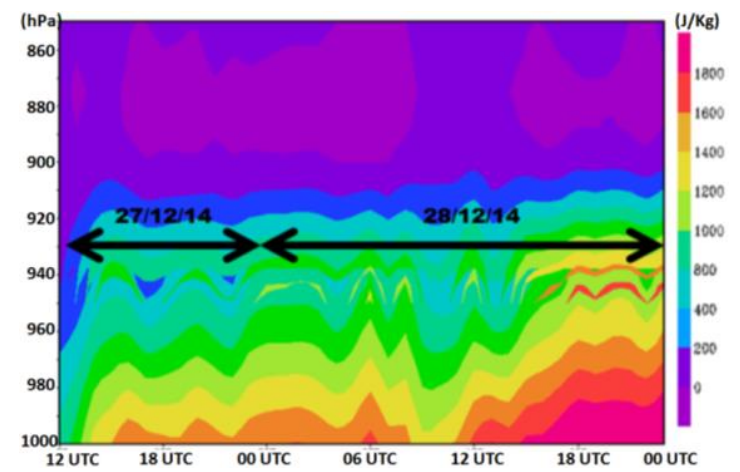

Gambar 7. Diagram hovmoller CAPE titik 1.5 LS 108.5 BT Sumbu x waktu dan y ketinggian.

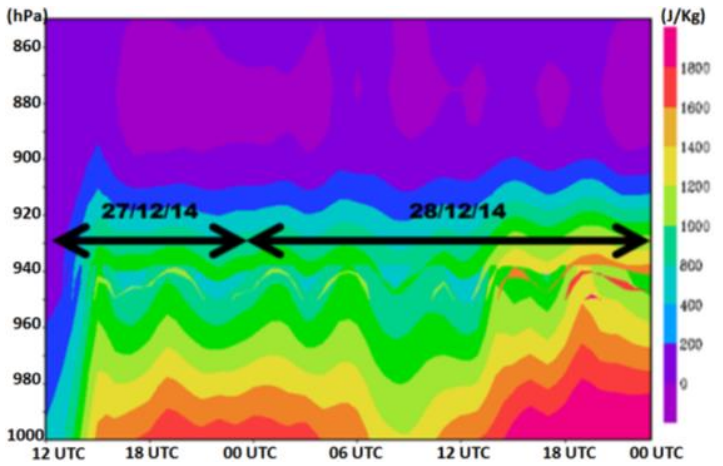

Gambar 8. Diagram hovmoller CAPE titik 1.5 LS

109.0 BT Sumbu x waktu dan y ketinggian.

Hasil keluaran model (Gambar 7 dan Gambar 8) menunjukkan bahwa pada tanggal tersebut terjadi kenaikan CAPE dibandingkan hari sebelumnya yaitu mencapai $1000 \mathrm{~J} / \mathrm{Kg}$ hingga diatas $1800 \mathrm{~J} / \mathrm{Kg}$. Fenomena ini menandakan atmosfer dalam kondisi labil (moderate instability) sehingga terdapat adanya potensi pertumbuhan awan-awan konvektif. 


\subsubsection{Curah Hujan}

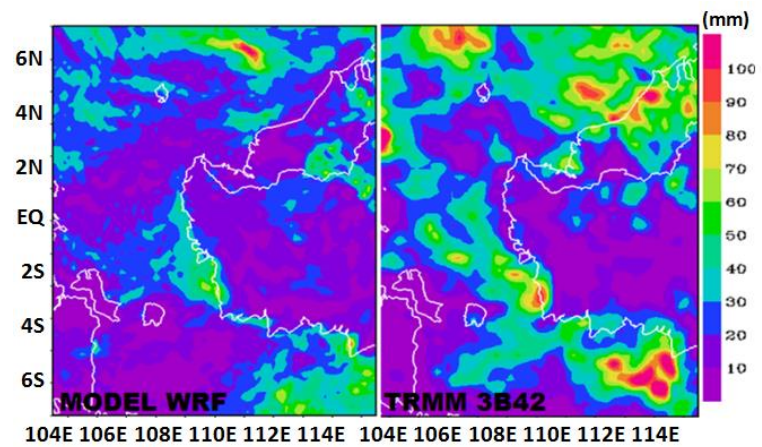

Gambar 9. Curah hujan Model dan TRMM tanggal 28 Desember 2014.

Hasil keluaran model WRF-ARW dengan data TRMM 3B42 (Gambar 9) menunjukkan secara umum memiliki pola sebaran spasial yang sama. Selain itu ketika terjadi Borneo vortex pada tanggal 28 Desember 2014 terdapat konsentrasi curah hujan di Laut Cina Selatan, Selat Karimata dan Kalimantan bagian selatan. Hal ini sesuai dengan teori Chang dkk[3] yaitu pada hari-hari terdapat Borneo vortex, kenaikan massa udara (enhanced area) terjadi di Laut Cina Selatan dekat ekuator dan Kalimantan sehingga pada wilayah tersebut terjadi peningkatan curah hujan.

\subsubsection{Uji Kehandalan Model}

Uji kehandalan model secara sederhana dilakukan dengan mengambil titik sampel untuk mendapatkan nilai curah hujan secara acak. Kemudian dibandingkan dengan data TRMM 3B42 dan diperoleh hasil sebagai berikut :

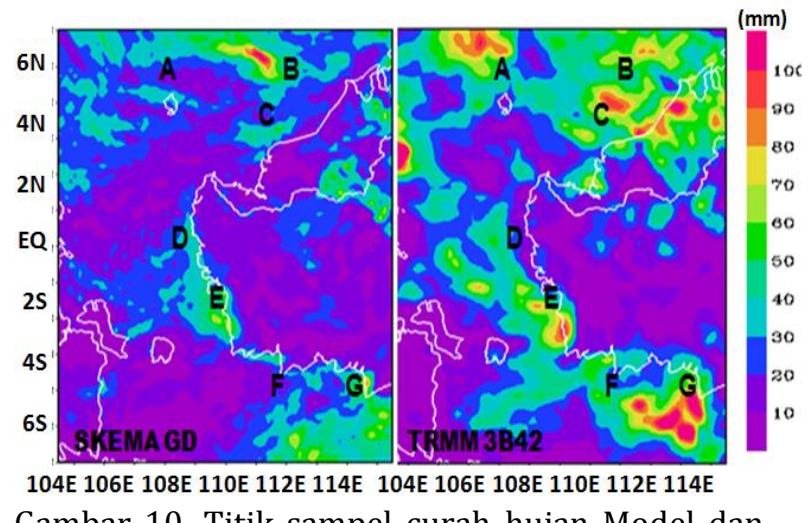

Gambar 10. Titik sampel curah hujan Model dan TRMM tanggal 28 Desember 2014.
Tabel 2. Curah hujan Model dan TRMM 3B42

\begin{tabular}{ccll}
\hline $\begin{array}{c}\text { Nama } \\
\text { Titik }\end{array}$ & Lokasi & $\begin{array}{l}\text { Model } \\
\text { WRF }\end{array}$ & $\begin{array}{l}\text { TRMM } \\
\text { 3B42 }\end{array}$ \\
\hline A & 5.0 LU - 107.5 BT & 24.04 & 52.92 \\
B & $5.0 \mathrm{LU}-112.5 \mathrm{BT}$ & 26.14 & 62.64 \\
C & 3.5 LU - 111.5 BT & 17.73 & 69.27 \\
D & $0.5 \mathrm{LU}-108.0 \mathrm{BT}$ & 15.14 & 34.12 \\
E & $1.5 \mathrm{LS}-109.0 \mathrm{BT}$ & 26.07 & 40.75 \\
F & $5.0 \mathrm{LS}-112.5 \mathrm{BT}$ & 26.14 & 62.64 \\
G & $5.0 \mathrm{LS}-115.0 \mathrm{BT}$ & 18.41 & 63.03 \\
\hline
\end{tabular}

Berbeda dengan hasil perbandingan curah hujan secara spasial (Gambar 9), hasil perbandingan curah hujan dengan titik-titik lokasi koordinat sampel (Gambar 10 dan Tabel 2) menunjukkan model WRF-ARW underestimate terhadap data TRMM 3B42.

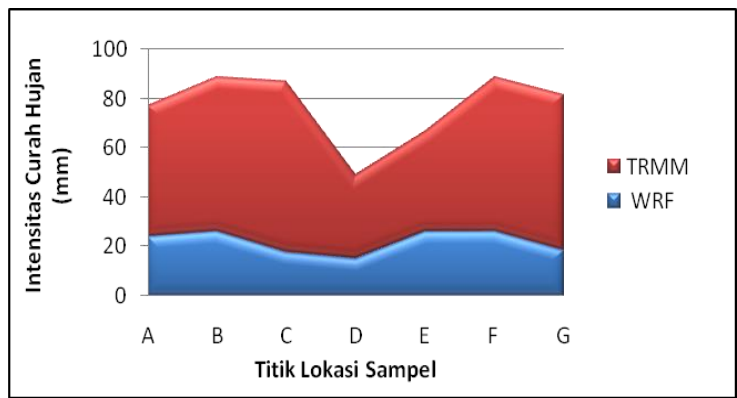

Gambar 11. Grafik perbandingan curah hujan Model dan TRMM 3B42.

Hal ini disebabkan proses perhitungan yang dilalui dalam skala sub grid dengan resolusi yang terbatas, sehingga akan sangat sulit untuk sebuah model manapun untuk menghasilkan nilai yang persis dan identik dengan data pembanding lainnya.

\section{Kesimpulan}

Telah teridentifikasi adanya Borneo vortex yang terbentuk pada tanggal 28 Desember 2014 melalui model WRF-ARW. Adanya vortex ini menimbulkan belokan angin dan arus konvergen di Laut Cina Selatan, Selat Karimata, dan Kalimantan bagian selatan. Selain itu karena kondisi atmosfer yang tidak stabil dan kelembaban udara yang tinggi maka hal ini dapat memicu terbentuknya awan-awan konvektif pada ketiga wilayah tersebut. Uji kehandalan sederhana menunjukkan secara spasial model mampu memetakan wilayah-wilayah yang terdapat hujan 
POSITRON, Vol. VII, No. 1 (2017), Hal. 01 - 07

http://dx.doi.org/10.26418/positron.v7i1.19349

dengan baik, namun dari segi intensitas hujan, angka yang dihasilkan model masih dibawah data pembanding dalam hal ini data TRMM 3B42.

\section{Daftar Pustaka}

[1] Anip, M.HM ., Lupo, A. R. 2011. Climatological Study of Borneo Vortex during Northern Hemisphere Winter Monsoon. Poster in Conference World Research Climate Programme (WRCP) 2011. Colorado-USA.

[2] Braesicke, P., Hai, O.S. dan Samah, A.A. 2012. Properties of strong off-shore Borneo vortices: a composite analysis of flow pattern and composition as captured by ERA-Intem. Journal of The Royal Meteorological Society 13:128-132.

[3] Chang, C.P., Harr, P.A., dan Chen, H.J. 2005. Synoptic Disturbance over the Equatorial South China Sea and Western Maritime Continent during Boreal Winter. Monthly Weather Review. Vol. 133.489-503

[4] Anip, M.H.M., Lupo, A. 2012. Interannual and Interdecadal Variability of The Borneo Vortex During Boreal Winter Monsoon. University of Missouri Columbia, USA.

[5] Houze, R. A. Jr., S. G. Geotis, F. D. Marks and A. K. West, 1981.Winter monsoon convection in the vicinity of North Borneo, Part I: Structure and time variation of the clouds and precipitation. Monthly Weather Review., 109, 1595-1614.

[6] Johnson, R. H., and D. L. Priegnitz, 1981. Winter monsoon convection in the vicinity of north Borneo, Part II: Effects on large-scale fields. Monthly Weather Review., 109, 16151628.

[7] Sulung, G., Priyanka,M., Saraswati, N., Nurfiena., Ricardo,R.L.G., 2011. Pengaruh Parameterisasi Kumulus terhadap Simulasi Angin Kencang di Makassar dengan Menggunakan WRF.Bandung: ITB.

[8] Google Maps, 2016. Area Laut Cina Selatan, Selat Karimata, Kalimantan Bagian Barat dan Selatan. https://www.google.co.id/maps/@$0.0220057,109.3366826,1604212 \mathrm{~m} /$ data $=! 3$ $\mathrm{m} 1$ !1e3?hl=en diakses pada 4 Maret 2017
ISSN: 2301-4970 (print )

ISSN: 2549-936X (online)

[9] https://rda.ucar.edu/datasets/ds083.2/ind ex.html\#sfol-wl-/data/ds083.2?g=2 diakses pada 9 Januari 2015

[10] https://mirador.gsfc.nasa.gov/cgi-bin/mira dor/presentNavigation.pl?tree=project\&data set=3B $42: \% 203$ Hour $\% 200.25 \% 20 x \% 200.25$ $\% 20$ degree $\% 20$ merged\%20TRMM\%20and $\% 20$ other\%20satellite\%20estimates\&projec $\mathrm{t}=\mathrm{TRMM} \&$ dataGroup $=$ Gridded \&version $=007$ diakses pada 20 Oktober 2015

[11] http://satelit.bmkg.go.id/BMKG/index.php? pilih=6 diakses pada 27-31 Desember 2014

[12] http://www.bom.gov.au/australia/charts/ar chive/index.shtml diakses pada 15 Januari 2015

[13] http://www.wrf-model.org/index.php diakses pada 4 Januari 2015

[14] Comet Program, 2000, Meteorology Education \& Training (MetEd) : How Model Produce Precipitation and Clouds, University Corporation for Atmospheric Research (UCAR), Colorado.

[15] Holton, J. R. 2004. An Introduction to Dynamic Meteorology (4th ed.). Elsevier Academic Press. San Diego-California.

[16] Lynch, A.H dan Cassano, J.J. 2006. Applied Atmospheric Dynamics. John Wiley and ons Ltd, West Sussex P019 8SQ, England

[17] http://www.spc.noaa.gov/sfctest/help/sfcoa. html diakses pada 20 Oktober 2015 